\title{
FASTING BLOOD GLUCOSE LEVEL IN PATIENTS PRESENTING WITH ERECTILE DYSFUNCTION
}

\author{
Aysun Isiklar, ${ }^{1}$ Sibel Ocak Serin ${ }^{2}$ \\ ${ }^{1}$ Department of Internal Medicine, Acibadem Hospitals Group, Istanbul, Turkey (current workplace) \\ ${ }^{2}$ Department of Internal Medicine, University of Health Sciences, \\ Umraniye Training and Research Hospital, Istanbul, Turkey
}

Primljen/Received 28. 06. 2021. god.

Abstract: Introduction: An increase in diabetes mellitus (DM) causes different complaints and concerns. This retrospective cross-sectional study aimed to test fasting blood glucose (FBG) levels in patients presenting with erectile dysfunction (ED).

Materials and Methods: The patients included in the study were divided into two groups. Test group $\mathrm{X}$ consisted of 92 male patients who were referred to the urology outpatient clinic with the complaint of ED and did not have a previous DM history. Control group $\mathrm{Y}$ was formed with the same number of patients who applied to the internal medicine outpatient clinic for other complaints.

Results: The mean FBG levels were $133.7 \pm 77.3$ $\mathrm{mg} / \mathrm{dL}$ in the group with ED and $102.7 \pm 24.3 \mathrm{mg} / \mathrm{dL}$ in the control group. There was a significant correlation between the two groups in impaired fasting glucose (IFG) values $(p<0.05)$.

Conclusion: Therefore, the measurement of fasting blood sugar is an essential diagnostic step in evaluating patients with ED.

Keywords: fasting blood glucose, erectile dysfunction, diabetes mellitus.

\section{INTRODUCTION}

Erectile dysfunction (ED-impotence) is the inability to achieve or maintain an adequate erection for satisfactory sexual performance (1). ED is a common condition since $22 \%$ of men in the United States experience it and will affect 322 million males worldwide by 2025 (2). The general belief is that $50 \%$ of men older than 40 years have ED (1), which impairs the quality of life to a great extent (3).

The emergence of clinical signs of ED is quite complicated. The causes can be roughly classified as organic, psychological, and mixed. ED occurs due to
Prihvaćen/Accepted 03. 08. 2021. god.

any ailments during physiological processes, such as the central nervous system, peripheral nervous system, hormonal system, and vascular systems. The most crucial cause is vasculogenic etiology. Some genetic factors also play the same role (4). The incidence of ED increases with age, similar to the increase in other age-related diseases (coronary artery disease, hypertension, diabetes). Among these, diabetes mellitus (DM) is the most common risk factor for ED. ED has been reported 4.2 times more in diabetic patients than in the non-diabetic population. In patients with $\mathrm{ED}$, the rate of hypertension was found to be $60 \%$, hypercholesterolemia $40 \%$, coronary artery disease $20 \%$, DM $11 \%$, and depression $68 \%$ (5).

$\mathrm{DM}$ is a known cause of ED. Many systematic reviews and meta-analyses have revealed that ED prevalence in type 1 diabetes is $37.5 \%$ and $66.3 \%$ in type 2 diabetes. The vascular and neurogenic mechanisms cause this disorder $(6,7)$.

Different diagnostic methods for diabetes are defined by the World Health Organization (WHO) and the International Diabetes Federation (IDF), such as fasting blood glucose (FBG), oral glucose tolerance test (OGTT), second-hour plasma glucose (PG), hemoglobin $\mathrm{A} 1 \mathrm{C}$, and random $\mathrm{PG}(8)$. Impaired Fasting Glucose (IFG) is not enough to identify individuals at risk in an easy way. IFG is a transition between normal glucose levels and impaired glucose tolerance (IGT) (8). Even this level of hyperglycemia is an increased risk factor for metabolic diseases.

This study aimed to determine fasting blood sugar levels in patients presented with ED for the first time.

\section{Materials and Methods}

The study was performed in an outpatient clinic from patients followed up between October 2017 and 
December 2017. The patients included in the study were divided into two groups. Test group $\mathrm{X}$ consisted of 92 male patients who were referred to the urology outpatient clinic with the complaint of ED and no previous DM history. Control group Y was formed with the same number of patients applied to the internal medicine outpatient clinic for other complaints. We recorded the age, gender, and FBG levels of the patients. According to IDF 2015 data, those with FBG levels of $100-125 \mathrm{mg} / \mathrm{dL}$ were considered as IFG and those with FBG levels of $>126 \mathrm{mg} / \mathrm{dL}$ as DM.

Statistical analyses were performed in the NCSS (Number Cruncher Statistical System) 2007 (Kaysville, Utah, USA) program. We used descriptive statistical methods (frequency, percentage, mean, and standard deviation) to assess the data, and the relationship between variables was assessed using Spearman's rho correlation test. The significance level for all analyses was selected as $\mathrm{p}<0.05$.

\section{Ethics statement}

Since our study is retrospectively conducted, we did not get informed consent forms from patients. Approval was obtained from the local ethics committee (approval\#16867222/604.01.01) and conducted according to the Helsinki Declaration and Good Clinical Practices guideline.

Name of the institution where the work was done:

- Department of Internal Medicine, Health Science University Sancaktepe Sehit Profesor İlhan Varank Training and Research Hospital, Istanbul, Turkey.

Table 1. Distribution of demographic characteristics

\begin{tabular}{|c|c|c|}
\hline & No ED & ED \\
\hline $\begin{array}{c}\text { Age } \\
\text { Mean } \pm S D\end{array}$ & $45.65 \pm 10.52$ & $46.91 \pm 10.31$ \\
\hline $\begin{array}{c}\text { Fasting blood } \\
\text { glucose } \\
\text { (FBG) } \\
\text { Mean } \pm S D\end{array}$ & $102.68 \pm 24.26$ & $133.65 \pm 77.33$ \\
\hline
\end{tabular}

\section{RESULTS}

A total of 184 subjects were included in the study by a systematic random sampling method. All patients were male. The mean age was $45.78 \pm 10.3$ years in both groups (Table 1). The mean FBG levels were $133.7 \pm 77.3 \mathrm{mg} / \mathrm{dL}$ in the group with ED and 102.7 \pm $24.3 \mathrm{mg} / \mathrm{dL}$ in the control group. There was a significant correlation between the two groups in IFG values $(\mathrm{p}<0.05)$ (Table 2).

\section{DISCUSSION}

DM is known to be in the etiology of ED. Previous studies demonstrated that ED might be among the first symptoms of coronary artery disease (9). We aimed to evaluate fasting blood glucose levels and their relation to ED presentation.

The risk of developing type $2 \mathrm{DM}$ in the population with IFG between 3 and 5 years is $51.3 \%$, and this risk in the IFG and IGT population within five years is $33-36 \%$. Prediabetes is seen in $25-62 \%$ of patients with idiopathic peripheral neuropathy. Neuropathy is seen in $13-21 \%$ of the population with impaired glucose tolerance (10).

ED occurs as a consequence of the development of autonomic neuropathy in diabetic patients (11). Neuropathy presenting in IFG and early DM is similar. In IFG, neuropathy is observed in $30-50 \%$ of patients with IGT and about $40 \%$ of early diabetics, suggesting early neuropathy involvement. Between 25 and $62 \%$ of patients with idiopathic peripheral neuropathy are prediabetes. 13 to $21 \%$ of IGT patients also have neuropathic findings, and 11 to $25 \%$ of patients with prediabetes have peripheral neuropathy. Neuropathic pain has been reported in 13 to $21 \%$ of patients (12).

Patients with DM longer than ten years tend three times more likely to develop ED than those with a history of fewer than five years (13). There is also increasing evidence that ED is associated with glycemic control. The mean FBG level measured was 133,7 \pm $77,3 \mathrm{mg} / \mathrm{dL}$ in the group of ED complaints and 102,7 \pm $24,3 \mathrm{mg} / \mathrm{dL}$ in the control group.

Table 2. Fasting blood glucose levels

\begin{tabular}{|c|c|c|c|}
\hline Variable & No ED & ED & p \\
\cline { 1 - 2 } $\begin{array}{c}\text { Fasting blood glucose } \\
\text { (FBG) }\end{array}$ & $\underline{\mathbf{n}}_{1}(\mathbf{\%})$ & $\left.\underline{\underline{\mathbf{n}}}_{\underline{2}} \mathbf{\%}\right)$ & \multirow{2}{*}{$\mathrm{p}=0.18(>0.05)$} \\
\cline { 1 - 2 } $\begin{array}{c}\text { Normoglycemic } \\
(<100 \mathrm{mg} / \mathrm{dL})\end{array}$ & $53(28.8 \%)$ & $41(22.3 \%)$ & $\mathbf{p}=\mathbf{0 . 0 1}(<\mathbf{0 . 0 5})$ \\
\cline { 1 - 3 } $\begin{array}{c}\text { Impaired fasting } \\
\text { glucose (IFG) } \\
(100-126 \mathrm{mg} / \mathrm{dL})\end{array}$ & $39(21.1 \%)$ & $51(27.8 \%)$ & \\
\hline Total & 92 & 92 & \\
\hline
\end{tabular}


ED occurs over time in more than $50 \%$ of IGT patients and $10-18 \%$ of the diabetic population. Metabolic tissue damage caused by hyperglycemia causes microvascular complications $(14,15)$. Therefore, FBG should be investigated in men who have ED complaints (16). Other studies observed similar results. ED is associated not only with undiagnosed DM but also with IFG (17).

ED develops due to atherosclerosis and neuropathic changes in the corporal erectile tissue due to changes, such as smooth muscle degeneration, endothelial cell dysfunction, and abnormal collagen deposition (17). Autonomic neuropathy causes impaired endothelium-dependent and independent vasodilatation without clinical macrovascular symptoms. Undiagnosed autonomic neuropathy increases the risk of ED in peripheral neuropathy. Blood flow becomes insufficient due to endothelial dysfunction and autonomic neuropathy (18). This condition is a critical marker for screening for silent coronary artery disease (CAD) (19).

IFG is only a clinical presumptive diagnosis, not a clinical entity. It must be followed up for the long term, and necessary precautions regarding DM should be taken. Available data suggest that there is a lower risk for progression of IFG to diabetes (15). This study observed that the IFG and IGT rates were higher in the patients with a complaint of ED. Our results were also similar to the previous studies in the literature $(17,20)$.

The study of Olafimihan et al. showed that IFG was statistically associated with ED (about $60 \%$ of this group had ED) (20). Other studies have reported similar results in the literature (17). IFG is not a clinical entity; it is a risk category on early medical presentation of diabetes and cardiovascular diseases.

The impact of ED on social life is significant. The number of patients is low due to sexual taboos, especially in developing and underdeveloped countries.
Only 10 percent of men between 18 and 60 in Turkey reach out to a doctor with ED complaints. In our study, the control group did not ask for help for this kind of complaint, so this rate is more than we found it.

In this study, the blood sugar level in the ED group was higher than in the control group. Early medical presentations, such as IFG and ED, are risk factors for diabetes $(21,22)$.

These findings have crucial clinical implications for physicians. Asking questions that lead to the screening of these risk groups related to sexual health would make a change to prevent disease progression.

\section{CONCLUSION}

The first symptom in patients may be ED. Therefore, measuring fasting blood glucose is an essential diagnostic step.
Abbreviation
DM - diabetes mellitus
FBG - fasting blood glucose
ED - erectile dysfunction
IFG - impaired fasting glucose

\section{Acknowledgment}

None.

Conflict of Interests: The authors declare that there are no conflicts of interest related to this article.

Funding: None

\section{Licensing}

This work is licensed under a Creative Commons Attribution 4.0 International (CC BY 4.0) License

\title{
Sažetak
}

\section{NIVO GLUKOZE U KRVI KOD PACIJENATA SA EREKTILNOM DISFUNKCIJOM}

\author{
Aysun Isiklar, ${ }^{1}$ Sibel Ocak Serin ${ }^{2}$ \\ ${ }^{1}$ Department of Internal Medicine, Acibadem Hospitals Group, Istanbul, Turkey (current workplace) \\ ${ }^{2}$ Department of Internal Medicine, University of Health Sciences, Umraniye Training and Research Hospital, Istanbul, Turkey
}

Uvod: Porast dijabetesa (DM) izaziva različite žalbe i zabrinutosti. Ova retrospektivna studija preseka imala je za cilj ispitivanje nivoa glukoze u krvi natašte (FBG) kod pacijenata sa erektilnom disfunkcijom (ED).

Materijali i metode: Pacijenti uključeni u studiju bili su podeljeni u dve grupe. Grupu ispitanika, označenu kao grupu X činilo je 92 pacijenta muškog pola koji su upućeni u urološku ambulantu sa tegobama vezanim za erektilnu disfunkciju ED bez anamnestičkih podataka vezanih za dijabetes melitus. Kontrolna grupa Y je formirana sa istim brojem pacijenata koji su se obratili internističkoj ambulanti zbog drugih tegoba.

Rezultati: Prosečni nivoi FBG bili su 133,7 \pm 77,3 $\mathrm{mg} / \mathrm{dL}$ u grupi sa ED i 102,7 $\pm 24,3 \mathrm{mg} / \mathrm{dL}$ u kontrolnoj grupi. Postojala je značajna korelacija između dve grupe u oslabljenim vrednostima glukoze (IFG) $(\mathrm{p}<0,05)$.

Zaključak: Merenje šećera u krvi natašte bitan dijagnostički korak u proceni pacijenata sa ED.

Ključne reči: glukoza u krvi natašte, erektilna disfunkcija, dijabetes melitus. 


\section{REFERENCES}

1. The National Institutes of Health (NIH). Consensus development conference on impotence. Dec.1992.

2. Schwarz ER, Kapur V, Bionat S, Rastogi S, Gupta $\mathrm{R}$, Rosanio $\mathrm{S}$. The prevalence and clinical relevance of sexual dysfunction in women and men with chronic heart failure. Int J Impot Res. 2008; 20(1): 85-91. doi: 10.1038/sj.ijir.3901613.

3. Latini DM, Penson DF, Lubeck DP, Wallace KL, Henning JM, Lue TF. Longitudinal differences in disease specific quality of life in men with erectile dysfunction: results from the Exploratory Comprehensive Evaluation of Erectile Dysfunction study. J Urol. 2003; 169(4): 1437-42. doi: 10.1097/01. ju.0000049203.33463.9e.

4. Lopushnyan NA, Chitaley K. Genetics of erectile dysfunction. J Urol. 2012; 188(5): 1676-83. doi: 10.1016/j.juro.2012.07.008.

5. Johannes CB, Araujo AB, Feldman HA, Derby CA, Kleinman KP, McKinlay JB. Incidence of erectile dysfunction in men 40 to 69 years old: longitudinal results from the Massachusetts male aging study. J Urol. 2000; 163(2): 460-3.

6. Miner M, Seftel AD, Nehra A, Ganz P, Kloner RA, Montorsi P, et al Prognostic utility of erectile dysfunction for cardiovascular disease in younger men and those with diabetes. Am Heart J. 2012; 164(1): 21-8. doi: 10.1016/j.ahj.2012.04.006.

7. Nehra A, Jackson G, Miner M, Billups KL, Burnett $\mathrm{AL}$, Buvat J, et al. The Princeton III Consensus recommendations for the management of erectile dysfunction and cardiovascular disease. Mayo Clin Proc. 2012; 87(8): 766-78. doi: 10.1016/j.mayocp.2012.06.015.

8. World Health Organization \& International Diabetes Federation. Definition and diagnosis of diabetes mellitus and intermediate hyperglycaemia: report of a WHO/IDF consultation. World Health Organization. 2006. https://apps.who.int/ iris/handle/10665/43588.

9. Hanley AJ, Karter AJ, Williams K, Festa A, D'Agostino RB Jr, Wagenknecht LE, et al. Prediction of type 2 diabetes mellitus with alternative definitions of the metabolic syndrome: the Insulin Resistance Atherosclerosis Study. Circulation. 2005 ; 112(24): 3713-21. doi: 10.1161/CIRCULATIONAHA.105.559633.

10. Hoffman-Snyder C, Smith BE, Ross MA, Hernandez $\mathrm{J}$, Bosch EP. Value of the oral glucose tolerance test in the evaluation of chronic idiopathic axonal polyneuropathy. Arch Neurol. 2006; 63(8): 1075-9. doi: 10.1001/archneur.63.8.noc50336.
11. Yesil Y, Altun BU. Electroneuromyiographic examination of peripheral nerves and brake in individuals with impaired fasting glucose, impaired glucose tolerance, well-controlled and poorly-controlled diabetes mellitus. Master thesis, Trakya University Faculty of Medicine. 2006.

12. Singleton JR, Smith AG, Russell JW, Feldman EL. Microvascular complications of impaired glucose tolerance. Diabetes. 2003; 52(12): 2867-73. doi: 10.2337/diabetes.52.12.2867.

13. El-Sakka AI, Tayeb KA. Erectile dysfunction risk factors in noninsulin dependent diabetic Saudi patients. J Urol. 2003; 169(3): 1043-7. doi: 10.1097/01.ju.0000050080.21839.f9.

14. Thethi TK, Asafu-Adjaye NO, Fonseca VA. Erectile dysfunction. Clin. Diabetes. 2005; 23: 105-13.

15. Singleton JR, Smith AG, Russell JW, Feldman EL. Microvascular complications of impaired glucose tolerance. Diabetes. 2003; 52(12): 2867-73. doi: 10.2337/diabetes.52.12.2867.

16. Moulik PK, Hardy KJ. Hypertension, anti-hypertensive drug therapy and erectile dysfunction in diabetes. Diabet Med. 2003; 20(4): 290-3. doi: 10.1046/j.1464-5491.2003.00911.x.

17. Grover SA, Lowensteyn I, Kaouache M, Marchand S, Coupal L, DeCarolis E, et al. The prevalence of erectile dysfunction in the primary care setting: importance of risk factors for diabetes and vascular disease. Arch Intern Med. 2006; 166(2): 213-9. doi: 10.1001/archinte.166.2.213.

18. Hecht MJ, Neundörfer B, Kiesewetter F, Hilz MJ. Neuropathy is a major contributing factor to diabetic erectile dysfunction. Neurol Res. 2001; 23(6): 651-4. doi: 10.1179/ 016164101101198965.

19. Jensen J, Lendorf A, Stimpel H, Frost J, Ibsen H, Rosenkilde P. The prevalence and etiology of impotence in 101 male hypertensive outpatients. Am J Hypertens. 1999; 12(3): 271-5. doi: 10.1016/s0895-7061(98)00225-8.

20. Olafimihan KO, Ayinmode BA, Odeigah LO, Akande A. Erectile dysfunction in the aging man. International Journal of Medicine and Medical Sciences. 2010; 2(11): 342-6.

21. Fuller JH, Shipley MJ, Rose G, Jarrett RJ, Keen H. Coronary-heart-disease risk and impaired glucose tolerance. The Whitehall study. Lancet. 1980; 1(8183): 1373-6. doi: 10.1016/s0140-6736(80)92651-3.

22. Alberti KG. The clinical implications of impaired glucose tolerance. Diabet Med. 1996; 13(11): 927-37. doi: 10.1002/(SICI)1096-9136(199611)13:11<927::AID-DIA279 $>3.0 . \mathrm{CO} ; 2-\mathrm{E}$.

\section{Correspondence to/Autor za korespondenciju}

Aysun Dauti Isiklar M.D.

E-mail: aysunisiklar@gmail.com, Cell Phone: +905364179745, Address: Altunizade, Yurtcan Sokağı No: 1, 34662 Üsküdar/ISTANBUL/Turkey 